\title{
On Scientific Observation
}

\author{
By Lorraine Daston*
}

\begin{abstract}
For much of the last forty years, certain shared epistemological concerns have guided research in both the history and the philosophy of science: the testing of theory (including the replication of experiments), the assessment of evidence, the bearing of theoretical and metaphysical assumptions on the reality of scientific objects, and, above all, the interaction of subjective and objective factors in scientific inquiry. This essay proposes a turn toward ontology-more specifically, toward the ontologies created and sustained by scientific observation. Such a shift in focus would invite a rethinking of the neo-Kantian distinctions (along with their characteristic metaphors, such as "lenses," "filters," and "perspectives") that have, implicitly or explicitly, informed much of late twentieth-century history and philosophy of science. In particular, the current gap between psychology and epistemology might be bridged, if the psychology in question were collective rather than individual and the epistemology oriented toward discovery rather than warranting and testing.
\end{abstract}

\section{BEYOND EPISTEMOLOGY}

Observation is everywhere and nowhere in the history and philosophy of science. It is ubiquitous as an essential scientific practice in all the empirical sciences, both natural and human, and even arguably in mathematics in some of its exploratory phases. It is invisible because it is generally conceived to be so basic as to merit no particular historical or philosophical attention. It is true that in the mid-twentieth century some philosophers did take up the topic, but they did so for reasons that reinforced the view of scientific observation as primitive and passive. Logical positivists in quest of a "neutral observation language" embraced the doctrine of pure data, innocent of all theory and therefore qualified to adjudicate between competing theories: justice in science, as in law, is, on this account, ideally blind. For much the same reasons, their critics insisted that observation was "theory laden" and therefore incapable of providing a neutral judgment when theories clashed. ${ }^{1}$ In both cases, the primary interest of the philosophers of science was epistemological and framed in neo-Kantian terms: Was there or was there not such a thing as

\footnotetext{
* Max Planck Institute for the History of Science, Boltzmannstr. 22, D-14195 Berlin, Germany; ldaston@ mpiwg-berlin.mpg.de.

I am grateful to the participants of the Colloque de Cerisy "Exercices de métaphysique empirique" for their comments on an earlier version of this essay and to the Working Group on the History of Scientific Observation for mind-changing discussions, especially to Katharine Park and Gianna Pomata for helping me to think through the full implications of observation as an epistemic genre with a history. Bernard Lightman's editorial suggestions helped to right the balance between history and philosophy.

${ }^{1}$ For a brisk, perspicuous account of the philosophical positions in the mid-twentieth-century Anglophone
} 
scientific observation uncontaminated by theory? This was a question posed against a background of fears about how preconceived ideas, wishful thinking, and other subjective "lenses" might "filter" or "distort" objective empirical results. Given these epistemological fears, the less sophisticated observation could be made out to be, the closer to elementary perceptual processes, the better. But this rude simplicity was exactly what made observation too obvious to be interesting for late twentieth-century historians and philosophers no longer exercised by the debates over logical positivism, who instead explored active, complex experiment, with remarkable results. ${ }^{2}$

The aim of this brief essay is to argue in favor of a philosophical and historical inquiry into the ontology of scientific observation: how expert observation discerns and stabilizes scientific objects for a community of researchers. This is a question that lies somewhere between epistemology (which studies how scientific observers acquire knowledge about their chosen objects) and metaphysics (which addresses the ultimate reality of the entities observed-especially, in the case of scientific observation, under conditions highly mediated by instruments and ingenious setups). Ontology is about how scientists furnish the universe with objects that are amenable to sustained and probing investigation but that rarely correspond to the objects of everyday perception - even if the scientific objects in question are macroscopic, require no instruments in order to be made sensible, and are picked out by plainspoken terms in the vernacular (I shall offer a historical example of this sort later in this essay). For historians, in particular, a sustained examination of the history of scientific observation promises to bring to light variegated and refined practices, none of them simple or self-evident, that would connect the history of science to the history of the senses and the self, as well as enlarge the history of scientific experience. ${ }^{3}$

A historical and philosophical inquiry into the ontology of scientific observation will not circumvent epistemological questions entirely. But the kind of epistemology it will prompt will have as little use for the oppositions between observation and theory or between observation and experiment that have shaped philosophical (and also historical) views of observation since the mid-nineteenth century as it will for the quests of logical positivism. Eighteenth-century scientific observers would have been mightily puzzled by these stark oppositions, as well as by Claude Bernard's attempts to drive a wedge between "active" experiment and "passive" observation. For earlier practitioners and philosophers of observation, it was self-evident that observation uninformed by theory was not only impossible but senseless and that observation and experiment were inextricably intertwined. ${ }^{4}$ They did not conflate scientific observation with brute perception. ${ }^{5}$ A neutral

discussion of scientific observation see Ian Hacking, Representing and Intervening: Introductory Topics in the Philosophy of Natural Science (Cambridge: Cambridge Univ. Press, 1983), pp. 167-185.

${ }^{2}$ The literature generated by this research program is vast, but seminal book-length studies include Hacking, Representing and Intervening; Nancy Cartwright, How the Laws of Physics Lie (New York: Oxford Univ. Press, 1983); Steven Shapin and Simon Schaffer, Leviathan and the Air-Pump: Hobbes, Boyle, and the Experimental Life (Princeton, N.J.: Princeton Univ. Press, 1985); Peter Galison, How Experiments End (Chicago: Univ. Chicago Press, 1987); and David Gooding, Trevor Pinch, and Schaffer, eds., The Uses of Experiment: Studies in the Natural Sciences (New York: Cambridge Univ. Press, 1989).

${ }^{3}$ A forthcoming collective volume by the Working Group on the History of Scientific Observation at the Max Planck Institute for the History of Science will provide examples of such practices in both the human and natural sciences, from the thirteenth through the twentieth centuries.

${ }^{4}$ Claude Bernard, Introduction à l'étude de la médecine expérimentale [1865], ed. François Dagognet (Paris: Garnier-Flammarion, 1866), pp. 52-54, 71. For an earlier view see Benjamin-Samuel-Georges Carrard, Essai qui a remporté le prix de la Société Hollandoise des Sciences de Haarlem en 1770, sur cette question, qu'est-ce qui est requis dans l'art d'observer (Amsterdam: Chez Marc-Michel Rey, 1777), p. 245; cf. Jean Senebier, L'art d'observer, 2 vols. (Geneva: Cl. Philibert et Bart Chirol, 1775), Vol. 1, pp. 43-47.

${ }^{5}$ Even among the few champions of scientific observation in twentieth-century philosophy of science, such 
observation language, much less the passive registration of pure data, held no charm for them. These were rather Kantian dreams, possible only after the distinction between subjectivity and objectivity had established itself as the great epistemological divide among scientists as well as philosophers. ${ }^{6}$ An inquiry into the ontology of observation will probably not shift the epistemology back to pre-Kantian positions, although it is useful to recall that such positions are possible, given the depth and breadth of Kantian and neo-Kantian influence on both the history and the philosophy of science. Such an inquiry is, however, likely to blur the sharp Kantian distinction between epistemology and psychology, a point to which I will return in my conclusion. It is also likely to prompt a rethinking of the skeptical tinge of modern epistemology, so much more heavily weighted toward the wary avoidance of errors through experimental tests and evidentiary argument than toward the eager pursuit of the new: "not theory-using, but theory-finding," as Norwood Russell Hanson put it in the introduction to his aptly titled Patterns of Discovery (1958). ${ }^{7}$

\section{FURNISHING THE UNIVERSE}

It is habit that makes perception of a world possible. This is true of ordinary perception, as the sciences of vision since the seventeenth century have shown in remarkable detail: without, for example, the habit of seeing the same object as the same size, regardless of its distance, it would be very difficult to specify what it meant to be the "same" object. It is true in spades of expert perception, whether the trained eye in question is that of a bird-watcher, an art historian, or a pathologist. No one has explained this more clearly than the Polish bacteriologist and philosopher Ludwik Fleck, apropos of microscopic observations of bacteria: "Direct perception of form [Gestaltsehen] requires being experienced in the relevant field of thought. The ability directly to perceive meaning, form, and self-contained unity is acquired only after much experience, perhaps with preliminary training. At the same time, of course, we lose the ability to see something that contradicts the form. But it is just this readiness for directed perception that is the main constituent of thought style [Denkstil]." experience and training are required in order to make sense of this visual chaos, in order to be able to see things.

Fleck's insight is often assimilated to Thomas Kuhn's views on gestalt-switches between paradigms or to Hanson's analysis of theory-laden observation. But these readings have been, as it were, filtered through a neo-Kantian view of scientific observation as itself a kind of filter. In a recent article, Bruno Latour draws a sharp and telling contrast between this passage from Fleck and more Kuhnian formulations: "Fleck does not say, as in the usual Kantian-Kuhnian paradigm metaphor, that 'we see only what we know

as Michael Polanyi and Norwood Russell Hanson, there is a marked tendency to assimilate highly refined forms of observation to the simplest level of perception, with numerous references to the immediate and untutored perception of gestalts or even (in the case of Polanyi) to animal perception: Michael Polanyi, Personal Knowledge: Towards a Post-Critical Philosophy (1958; New York: Harper \& Row, 1964), pp. 76-77, 98-99; and Norwood Russell Hanson, Patterns of Discovery (1958; Cambridge: Cambridge Univ. Press, 1975), pp. $4-24$.

${ }^{6}$ See Lorraine Daston and Peter Galison, Objectivity (New York: Zone, 2007), esp. pp. 234-252.

${ }^{7}$ Hanson, Patterns of Discovery (cit. n. 5), p. 3.

${ }^{8}$ Ludwik Fleck, Genesis and Development of a Scientific Fact, trans. Fred Bradley and Thaddeus J. Trenn (1935; Chicago: Univ. Chicago Press, 1979), p. 92. On the context of Fleck's work see Ilana Löwy, trans. and ed., The Polish School of the Philosophy of Medicine: From Tytus Chalubinski (1820-1889) to Ludwik Fleck (1896-1961) (Dordrecht: Reidel, 1990). 
beforehand,' or that we 'filter' perceptions through the 'biases' of our 'presupposition.' Such a gap-bridging idea is on the contrary what he fights against because then time could not be part of the substance of fact genesis." "This is the key to Fleck's originality and continued relevance for a philosophy of scientific observation. For Fleck, learning to see like a scientist was a matter of accumulated experience-not only of an individual but of a well-trained collective. The fault line in epistemology did not run between subjects and objects, the great Kantian divide, but, rather, between inexperience and experience. Unlike the neo-Kantians, who worried about how the subjective mind could know the objective world, Fleck was concerned with how perception forged stable kinds out of confused sensations. For the neo-Kantians, the problem was the gulf between the subjective and the objective; for Fleck, it was generating order out of chaos. "Filters" or "theoretical spectacles" or "worldviews" in neo-Kantian history and philosophy of science are the preconditions for experience, always and necessarily in operation. In contrast to Kuhn's sudden gestalt-switches, Fleck's Gestaltsehen takes time: it is the result of experience as a gradual process rather than as the product of entrenched forms and categories.

Another way of putting this contrast is to say that Fleck was more interested in ontology than in epistemology. He certainly did probe questions of how we know, but his most remarkable insights were about what we know - those scientific facts of his title. In at least this sense, he was post-Kantian-or perhaps pre-Kantian, almost Aristotelian. Aristotle's epistemological machinery was compact and lightweight; in contrast, his ontological apparatus of art and nature, substance and accidents, and the whole retinue of the categories was positively baroque. Aristotle's account of how experience eventually discerns universals out of particulars was, like Fleck's, modeled on perception working over time:

So from perception there comes memory, as we call it, and from memory (when it occurs often in connection with the same thing), experience; for memories that are many in number form a single experience. And from experience, or from the whole universal that has come to rest in the soul (the one apart from the many, whatever is one and the same in all those things), there comes a principle of skill and of understanding. ${ }^{10}$

From perception to memory to experience to "the whole universal": this is how observation builds up an ontology, even if conscious reason, the faculty of epistemology, hasn't an inkling as to how it's done.

Without these acquired habits of perception cultivated by observation, there would not only be no science; there would be no articulated visible (or auditory or tactile) world at all. This is the way perception furnishes the universe. It doesn't create the universe, but it does shape and sort, outlining sharp edges and arranging parts into wholes. In contrast to languages, which may be learned either by ear or by grammatical rules, there seems to be only one route to competent perception, and that royal road is habit. Only the infant or the beginning student must proceed step by step to learn to see the morphology of plants

\footnotetext{
9 Hanson, Patterns of Discovery (cit. n. 5), pp. 54-58; Thomas S. Kuhn, The Structure of Scientific Revolutions (1962: Chicago: Univ. Chicago Press, 1996), pp. 114-116 (see also Kuhn, "Foreword," in Fleck, Genesis and Development of a Scientific Fact, pp. vii-xi); and Bruno Latour, "A Textbook Case Revisited: Knowledge as a Mode of Existence," in The Handbook of Science and Technology Studies, ed. Edward J. Hackett, Olga Amsterdamska, Michael Lynch, and Judy Wacjman (Cambridge, Mass.: MIT Press, 2007), pp. 83-112.

${ }^{10}$ Aristotle, Posterior Analytics, 2.19.100a4-8, in Jonathan Barnes, ed., The Complete Works of Aristotle: The Revised Oxford Translation, 2 vols. (Princeton, N.J.: Princeton Univ. Press, 1984), Vol. 1, pp. 165-166.
} 
or the signature traces of elementary particles or the spectra of stars. The adult, the expert, a fortiori the virtuoso takes it all in in a flash, conscious of the product but not the process of perception.

Field naturalists have coined a term of art for the all-at-once-ness of virtuoso perception: "jizz." A British ornithologist explained the concept in a 1922 article:

A West Coast Irishman was familiar with the wild creatures which dwelt on or visited his rocks and shores; at a glance he could name them, usually correctly, but if asked how he knew them would reply, 'By their 'jizz.' . . . That mental picture recorded through the eye is accurate in proportion to our familiarity with the species; the more familiar we are the less we note except the jizz. The passing curlew may have a long curved bill, a pale lower back, a strong distinctive flight; we knew these characters were present, but we did not actually see them; we saw a curlew. Curlew flashed into the brain without pause for mental analysis, for we noted the jizz. I am often asked the question which the Irishman was asked; I know of no better answer than his. ${ }^{11}$

Sure, swift, and silent, "without pause for mental analysis," observation is grounded in long familiarity with the phenomena in question, be they curlews or streptococcus bacteria.

One could make too much of the darkling character of perception, especially in the context of scientific observation. Such learned abilities are not in principle "tacit"; nor are they simply another expression of bodily skill, though they are also that. It is perfectly possible to describe in considerable detail, as Fleck did, the stages by which perceptions coalesce into experience and above all to teach others to see in this way. The fact that a process cannot be reduced to a method or modeled by an algorithm or subjected to conscious introspection in all its aspects by no means implies that the process is irretrievably tacit, much less mystical, although that has indeed been the inference that much twentieth-century philosophy of science drew. Distinctions between the context of discovery and the context of justification, or, more generally, between psychology and epistemology, have robbed philosophers of all resources for talking about experience in Fleck's sense, on the dubious assumption that experience itself is mute: so-called tacit knowledge. ${ }^{12}$

If psychology is understood in neo-Kantian terms, as ipso facto about subjectivity-and individual subjectivity at that - then it is not hard to understand why philosophers of science in this tradition have lumped it together with the mysteries of creativity, inspiration, and other murky realms of the irrational and refused to have anything to do with it. The Romantic cult of the mad genius is simply the flip side of this philosophical distaste. Historians of science have also regarded psychology warily, as a doomed ambition to probe the innermost thoughts and intentions of historical actors: "mind reading." Historians' forays into the psychology of science have been largely confined to the biographies of individual scientists. If, however, psychology — or at least the psychology of perception-is conceived as structured and collective, on the analogy of language, then historical and philosophical disdain is more difficult to justify. To be sure, human perception depends on characteristics that are peculiar to the species and, in some cases, to individ-

${ }^{11}$ Thomas Coward, “Jizz," in Bird Haunts and Nature Memories (London: Warne, 1922), pp. 141-144, on pp. 141-142. I am grateful to Anne Secord for drawing my attention to this article.

12 Polanyi's own account of tacit knowledge in science asserts "complete continuity" between "a primitive tacit act like perception" and "the process by which we establish responsible convictions in the course of scientific research": Polanyi, Personal Knowledge (cit. n. 5), p. 314. 
uals. But scientific perception-especially when elevated to the level of systematic observation, often in carefully designed setups-is disciplined in every sense of the word: instilled by education and practice, checked and cross-checked both by other observers and with other instruments, communicated in forms - text, image, table-designed by and for a scientific collective over decades and sometimes centuries (as in the case of botanical descriptions of new species). This kind of perception may still be specific to the human species and historical context-it is not the "view from nowhere," independent of "the specifics of the individual's makeup and position in the world." ${ }^{13}$ But neither is there anything capricious or mystical about it.

Moreover, since at least the seventeenth century, scientific observers have themselves theorized their practices. They have not only written manuals on how to observe with this or that instrument; they have also written extensively on why observe, what to observe, and who should observe. The collective empiricism institutionally launched by seventeenth-century academies such as the Academia Naturae Curiosorum or the Royal Society of London depended on the recruitment and reciprocal calibration of observers in correspondence networks. This was most obvious in the case of weather observers, who were encouraged to standardize their instruments, hours of observation, and recording forms, but it also held for astronomy, anatomy, and natural history. ${ }^{14}$ Far from being a lowly art, plied by unlettered artisans and peasants, as it had been regarded earlier, or an inferior substitute for experiment, as it was later viewed, observation had by the early eighteenth century become an essential and ubiquitous scientific practice, an art in the service of science. It featured prominently in the titles of learned books and articles; its prestige surpassed that of both experiment and deduction; it was the yardstick by which savants took each other's measure; it was even possible to become a "genius of observation." 15 But even after observation was demoted to the status of handmaiden to experiment in mid-nineteenth-century philosophy of science, it continued to be a fundamental scientific practice - and arguably the one most likely to generate novelties, including new ontologies.

\section{A CLOUD THAT'S DRAGONISH: AN EXAMPLE OF HOW TO SEE THINGS COLLECTIVELY}

The ways in which observation generates new scientific objects are various and complex. The implicit processes of trained perception are the most fundamental, but they are linked to explicit tools, including standardized instruments, descriptions, and images. Since the

13 Thomas Nagel, The View from Nowhere (Oxford: Oxford Univ. Press, 1986), p. 5. On the genesis of scientific objects see Lorraine Daston, ed., Biographies of Scientific Objects (Chicago: Univ. Chicago Press, 2000); Ian Hacking, "Historical Ontology," in Historical Ontology (Cambridge, Mass.: Harvard Univ. Press, 2002), pp. 1-26; and Ursula Klein and Wolfgang Lefèvre, Materials in Eighteenth-Century Science: A Historical Ontology (Cambridge, Mass.: MIT Press, 2007). On the early history of botanical description see Brian W. Ogilvie, The Science of Describing: Natural Historv in Renaissance Europe (Chicago: Univ. Chicago Press, 2006).

${ }^{14}$ Gustav Hellmann, "Die Entwicklung der meteorologischen Beobachtungen in Deutschland, von den ersten Anfängen bis zur Einrichtung staatlicher Beobachtungsnetze," Abhandlungen der Preussische Akademie der Wissenschaften, Physisch-Mathematische Klasse, 1926, 1:1-25; Andrea Rusnock, "Correspondence Networks and the Royal Society, 1700-1750," British Journal for the History of Science, 1999, 32:155-169; Paula Findlen, Possessing Nature: Museums, Collecting, and Scientific Culture in Early Modern Italy (Berkeley: Univ. California Press, 1994); Ogilvie, Science of Describing; Katharine Anderson, Predicting the Weather: Victorians and the Science of Meteorology (Chicago: Univ. Chicago Press, 2005); and Jan Golinski, British Weather and the Climate of Enlightenment (Chicago: Univ. Chicago Press, 2007).

${ }^{15}$ Senebier, L'art d'observer (cit. n. 4), Vol. 1, pp. 15-16. 


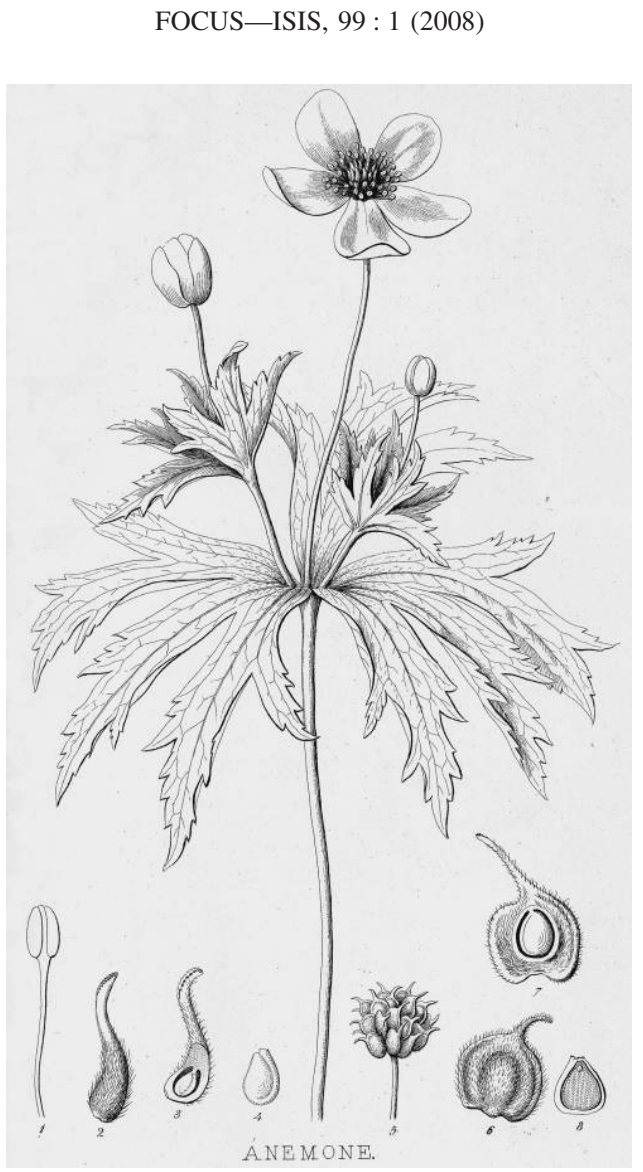

Figure 1. The genus Anemone. From Asa Gray and Isaac Sprague, The Genera of the Plants of the United States Illustrated from Nature, 2 vols. (New York: Putnam, 1848-1949), Plate 4.

sixteenth century, the images of botanical floras have been concerted attempts to represent a universal, not a particular. Linnaean Latin descriptions and illustrations are deliberately laconic, even schematic, because they must capture the essence of a species or an entire genus, as in the case of the image of the genus Anemone. (See Figure 1.) Ideally, these representations are distillations of many, perhaps hundreds of individual specimens seen by the botanist and mentally synthesized into the atlas image of record. They are crystallized experience in the Aristotelian sense: perception begets memory begets experience begets skill and understanding.

But the case of botany is too easy: the universalized plants of scientific ontology may not be identical with the particular plants of everyday experience, but doubt is seldom cast on the correspondence between them. More challenging are objects with no mundane counterpart, such as microbes or stellar spectra, for which new perceptual skills must be cultivated and honed if one is even to be able to detect patterns, much less classify them into robust and stable kinds. Even familiar objects accessible to naked-eye observation can present formidable challenges to collective perception, as the example of nineteenth- and twentieth-century cloud classifications testifies. The variety and mutability of clouds is proverbial. Leonardo da Vinci thought they were "images made by chance," a kind of celestial Rorschach blot upon which the artist might project creative fantasies. As the most 
recent (1975) International Cloud Atlas concedes, "clouds are continuously in a process of evolution and appear, therefore, in an infinite variety of forms." ${ }^{16}$ Even stay-at-home observers rooted to one spot on the globe had ample opportunity to document the ever-changing, ever-novel panorama of the clouds over their rooftops. Travelers were still more struck by the contrasts between the cloudscapes at home and those in other climes. ${ }^{17}$ Clouds in England and Italy displayed clear regional and seasonal differences; tropical clouds were almost as exotic as tropical flora and fauna for visitors from temperate zones. On the face of it, clouds seemed to be unpromising candidates for science, much less global science: too mutable to yield regularities and too local to support global generalizations.

Yet in the last quarter of the nineteenth century, meteorologists from all over the world tried to make a science out of the shapes of clouds. Cloud classification had begun earlier in the century, with the publication of Luke Howard's On the Modification of Clouds (1803)..$^{18}$ But by the 1870 s classification systems based on Howard's original tripartite scheme of cirrus, cumulus, and stratus had splintered and ramified in the prolific fashion of the clouds themselves. Worse still, names had come unstuck from the things they were supposed to designate: a Swedish, Portuguese, and British observer might all mean different things by "cirro-stratus"; observers beyond Europe diverged even more widely from one another. The International Cloud Atlas of 1896 was meant to make clear-cut scientific objects out of evanescent, protean clouds by teaching observers all over the world, on land and at sea, to see things in unison.

Observers had to learn to see the sky in the same way, to divide up the continuum of cloud forms at the same points, to connect the same words to the same things. Their attention had to be sharpened for the telling detail and blunted for the idiosyncratic one. This was the raison d'être for all scientific atlases, but the cloud atlas published in 1896 by the International Meteorological Committee confronted these challenges to the coordination of perception in extreme form: however much they might have differed about the choice of a characteristic anemone or kangaroo, atlas makers who documented such objects never doubted the real existence of anemones or kangaroos. ${ }^{19}$ But some experienced cloud observers did wonder about the reality of the cirro-cumulus, a fortiori about

\footnotetext{
${ }^{16}$ H. W. Janson, "The Image Made by Chance," in Essays in Honor of Erwin Panofsky, ed. Millard Meiss (De Artibus Opuscula, 50) (New York: New York Univ. Press, 1961), pp. 254-266; and World Meteorological Organization, International Cloud Atlas, Vol. 1: Manual on the Observation of Clouds and Other Meteors (Geneva: Secretariat of the World Meteorological Organization, 1975), p. 11.

${ }^{17}$ In the 1880 s the British meteorologist Ralph Abercromby sailed twice around the world to ascertain whether the main cloud types could indeed be found everywhere. He concluded that 90 percent of the world's clouds could be subsumed under the rubrics cirrus, cumulus, stratus, cirro-stratus, cirro-cumulus, strato-cumulus, and nimbus. These "common forms" were not only universal but more durable than rarer forms like festooned clouds (mammata). But their distribution was hardly uniform: cumulus was, for example, present year-round in the tropics but vanishingly rare in northern climates during the winter and perhaps hardly seen at all in arctic regions. Abercromby believed firmly in the existence of entities like the "true cumulus" (not to be confused with an inferior specimen with irregular lumps), but he also admitted that the physiognomy of the sky was as changeable and idiosyncratic as that of the human face. Ralph Abercromby, "On the Identity of Cloud Forms All Over the World, and on the General Principles by Which Their Indications Must Be Read," Quarterly Journal of the Royal Meteorological Society, 1887, 13:140-146.

${ }^{18}$ On the publication history of Howard's classification and slightly earlier attempts made by Jean-Baptiste Lamarck see Gustav Hellmann, "Einleitung," in Luke Howard, On the Modification of Clouds (1803), No. 3 in Neudrucke von Schriften und Karten über Meteorologie und Erdmagnetismus, ed. Hellmann (1894; Wiesbaden: Kraus Reprint, 1969), pp. 7-9.

${ }^{19}$ For a discussion of the raison d'être for scientific atlases see Daston and Galison, Objectivity (cit. n. 6), pp. $19-27$.
} 
that of the cirro-cumulus-caudatus or the cirro-cumulus-floccus. Moreover, scientific cloud observers could not and did not wish to supplant lay observers; on the contrary, the observatory-based meteorologists courted mariners, farmers, and amateur observers. This meant that technical, Latinate terms had somehow to be matched to lay, vernacular terms - and in several different languages. The internationalism of the cloud classifiers therefore ran deeper than the usual diplomacy of large scientific congresses in metropolises like Paris and Vienna. They had to figure out whether the colloquial French "ciel pommelé" was really the same as the English "mackerel sky"- and to train French and English observers to see both as a cirro-cumulus cloud. The coordination of word and image was essential, especially for those transitional cloud forms like the cirro-cumulus that admitted of infinite gradations and taxed the acuity of even the seasoned observer.

This example, which could easily be multiplied, shows how intricate the minuet of implicit perception and explicit observations could be. The designations, definitions, and, above all, characteristic atlas images of the cloud genera were matters of decades-long debate among meteorologists and lay observers. The criteria were spelled out, the grids of observation standardized. But ultimately the cloud observers had to grasp the physiognomy of a cloud at a glance; they had to master its "jizz." The nature of the objectmutating, blurring, dissolving — placed a premium on speed and experience, the fruits of implicit habit. These same characteristics posed a formidable challenge to collective perception, to the cultivation and calibration of shared habits.

The official cloud classification depended so heavily on such shared habits that it readily piggybacked on those already available in vernacular classifications. When in the 1880s meteorologists correlated the major systems of cloud classification then in use, they discovered that only three designations converged: cirrus, cumulus-and cirro-cumulus. ${ }^{20}$ In Hamburg and in Hong Kong, in Norway and in Portugal, all observers recognized these as "true" or "typical" or "genuine" cloud forms; here word and thing meshed. In Latin, "cirro-cumulus" was no more vivid or transparent than "strato-cumulus," but whereas almost no two systems could agree on the latter, they were unanimous in picking out the former-because it had already been picked out by a completely different terminology in the vernacular. The terms that did so appealed to diverse metaphors: sheep and mackerel, cobblestones and dappling. But all had succeeded in framing perception, in carving out an evanescent but striking cloud formation as a thing worthy of its own name. When in 1896 the first International Cloud Atlas appeared in a trilingual edition, the definitions of the cirro-cumulus in French and German added the vernacular terms: "Schäfchen," "Mouton."21 (See Figure 2.)

\footnotetext{
${ }^{20} \mathrm{H}$. Hildebrand Hildebrandsson, "Rapport sur la classification des nuages," in Congrès Météorologique International, tenu à Paris du 19 au 26 septembre 1889: Procès-verbaux sommaires, ed. Théodore Moureaux, Lasne, and Abbé Maze (Paris: Imprimerie Nationale, 1889), pp. 12-24, esp. pp. 15-16. "Stratus" and "nimbus" were used as terms in all the systems surveyed, but Hildebrandsson believed that they had different referents in different systems.

${ }^{21}$ H. Hildebrandsson, A. Riggenbach, and L. Teisserenc de Bort, eds., Atlas international des nuages/ Internationaler Wolken-Atlas/International Cloud Atlas (Paris: Gauthier-Villars et Fils, 1896), pp. 4, 14, 24. On linguistic imprecision and cloud observation see also Anderson, Predicting the Weather (cit. n. 14), pp. 228-232. On the challenges of meteorological photography, including that of clouds, see Jennifer Tucker, Nature Exposed: Photography as Eyewitness in Victorian Science (Baltimore: Johns Hopkins Univ. Press, 2005), pp. 126-158.
} 


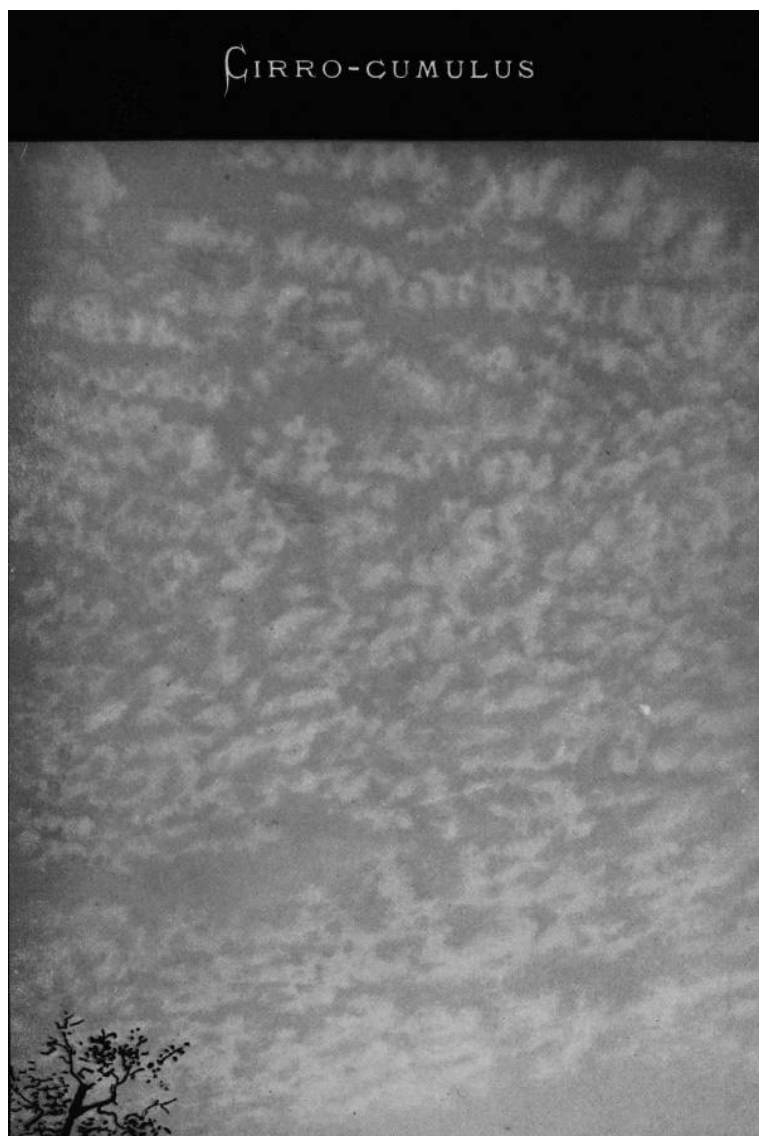

Figure 2. Cirro-cumulus cloud, photographed in Uppsala, Sweden, in 1890. From H. Hildebrandsson, A. Riggenbach, and L. Teisserenc de Bort, eds., Atlas international des nuages/ Internationaler Wolken-Atlas/International Cloud Atlas (Paris: Gauthier-Villars et Fils, 1896), Figure 6.

\section{ALL-AT-ONCE-NESS}

As the example of the cirro-cumulus cloud shows, collective habits of perception, even of ill-defined objects, need not be instilled by scientific training. But since the midnineteenth century and the institutionalization of higher education in science, formal scientific training has played a central role in instilling and honing shared ways of seeing things. It was in the seminars of Göttingen and Berlin, the laboratories of Cambridge and Baltimore, the field stations of Naples and New Zealand, that young researchers were inducted into Fleck's "thought collectives"-and, at least as significant, "seeing collectives." Yet we have only the barest beginnings of a history of scientific pedagogy and not even the rudiments of a philosophy. ${ }^{22}$ If, however, there is such a thing as ontology

${ }^{22}$ Book-length studies on scientific pedagogy include Kathryn M. Olesko, Physics as a Calling: Discipline and Practice in the Königsberg Seminar for Physics (Ithaca, N.Y.: Cornell Univ. Press, 1991); Nick Hopwood, Embryos in Wax: Models from the Ziegler Studio (Cambridge: Whipple Museum of the History of Science, 2002); Andrew Warwick, Masters of Theorv: Cambridge and the Rise of Mathematical Phvsics (Chicago: Univ. Chicago Press, 2003); David Kaiser, Drawing Theories Apart: The Dispersion of Feynman Diagrams in Postwar 
wrought by observation, this is where it is taking place, step by step, seminar by seminar, as apprentices learn to see like the masters. This schooling of the senses is probably not qualitatively different from that undergone by the fledgling musician, cook, or weaver-as Aristotle noted, the paths to skill, on the one hand, and to understanding, on the other, pass through the same stations of perception, memory, and experience. But the scientific path is greatly straitened by the demands of collective empiricism, which require a degree of coordination seldom achieved (or desired) in the traditional arts and crafts. Just because it is an ontology, not only a standard of connoisseurship, that scientific training must impart, convergence is indispensable. Novices must be taught to see things and to see the same things, a world held in common.

But it is not the common world that they learn to see. By ordinary standards, these are strange objects, strangely seen, often by strange people. Part of the deformation professionelle of scientific observers is a near-obsessive preoccupation with their objects of inquiry. This monomaniacal devotion to snakes or carbon atoms or algae-or, for that matter, to Greek verbs or Mannerist paintings - has been a theme more for satirists and novelists (and sometimes psychiatrists) than for historians, much less for philosophers. Yet it is perhaps not irrelevant to the specialized ontologies discerned and sustained by habits of specifically scientific perception. In his brilliant study of fifteenth-century Italian painting and the "period eye," the art historian Michael Baxandall remarks on the esoteric but intense pleasure afforded by the exercise of perceptual skill: "We enjoy our own exercise of skill, and we particularly enjoy the playful exercise of skills which we use in normal life very earnestly. If a painting gives us the opportunity for exercising a valued skill and rewards our virtuosity with a sense of worthwhile insights about that painting's organization, we tend to enjoy it: it is to our taste." 23

One may discount the testimony of an art historian concerning the pleasures of looking expertly at paintings, but that is precisely the point. Even if Baxandall's claim is false for the lay public indifferent to art, it is true for tutored eyes like Baxandall's-or, mutatis mutandis, for astronomers looking at stellar spectra or mycologists looking at fungi. The ontology of perceptual habit is reinforced by the aesthetic pleasures of skillful perception-and here "aesthetic" refers to the root sense of the word, relating to sensation, as well as to the more familiar modern sense as appreciation of beauty. Insofar as philosophers have discussed scientific observation at all, they have distinguished between seeing that and seeing as: for example, seeing that a very bright star appears at twilight and lingers at dawn versus seeing both evening and morning star as the same celestial object, the planet Venus. ${ }^{24}$ But there is also seeing well, which may be inextricably intertwined with the acquired ability to see $a$ s.

If this is true, there may be deep reasons why at least the perceptual aspects of scientific observation - the immediate and satisfying registration of the "jizz" of a curlew or a cloud or a cell-must be submerged in implicit habit, although other aspects, such as the communication and checking of results, are kept scrupulously explicit. There is something about the all-at-once-ness of habitual perception that stamps its ontologies with the imprimatur of the really real, the ontos on.

Science was and remains fertile in innovative visualization techniques, from the pie

Physics (Chicago: Univ. Chicago Press, 2005); and Kaiser, ed., Pedagogy and the Practice of Science: Historical and Contemporary Perspectives (Cambridge, Mass.: MIT Press, 2005).

${ }^{23}$ Michael Baxandall, Painting and Experience in Fifteenth-Century Italy, 2nd ed. (Oxford: Oxford Univ. Press, 1988), p. 34.

${ }^{24}$ Hanson, Patterns of Discovery (cit. n. 5), pp. 19-24. 
graph to magnetic resonance imaging. To call these images mere displays of data is to overlook their role in discovering and crystallizing new objects of scientific inquiry. They are as important for scientific ontology as they are for data management. Famous examples include Alexander von Humboldt's artfully colored and coded maps that showed the distribution of characteristic forms of vegetation (e.g., pines versus palms), which created what Humboldt called "landscape physiognomies": typical combinations of climate, topography, flora, and fauna that could be sized up in one sweeping glance by the seasoned traveler. Humboldtian maps turned indigestible tables of numbers into gestalts, as easily recognizable as a familiar face; columns and columns of temperature readings were converted into the globe-spanning curves of isotherms. (See Figure 3.) Humboldt was hopeful that the new technology of the panorama, which attracted flocks of visitors in metropolises like Berlin and London in the 1830s and 1840s with their 360-degree cityscapes, could be used to cultivate this Totaleindruck. ${ }^{25}$ One could, of course, concentrate on this or that meticulously painted detail, as many viewers did, but it was also possible to spin around and take in the entire panorama in one vertiginous glance. This is what Humboldt called "pressing together [diverse data] into one picture." 26

Whether in the form of Humboldt's maps or Francis Galton's composite photographs or a myriad other compact visualizations of a sprawl of data, all of these techniques aim at more than making the invisible visible. They aspire to all-at-once-ness, the condensation of laborious, step-by-step procedures into an immediate coup d'oeil, Humboldt's dizzying, integrating pirouette. What was a painstaking process of calculation and correlation-for example, in the construction of a table of variables-becomes a flash of intuition. And all-at-once intuition is traditionally the way that angels know, in contrast to the plodding demonstrations of humans.

The most celebrated ontology based on intuition had nothing to do with empirical observation. Descartes's "clear and distinct ideas" result from the mind communing with itself: "I will close my eyes, I will stop my ears, I will muffle all my senses, I will even erase from my thoughts all images of physical bodies, ... and thus concentrating solely on myself and considering my interior, I will try to become gradually familiar with myself." But Descartes was also susceptible to the attractions of all-at-once-ness. As Ian Hacking remarks: "Descartes' God is no prover. A proof might help a person see some truth, but only because people have poor intellectual vision. It used to be held that angels did not need to reason. Although commendably reticent about angels, Descartes has just such an attitude to reasoning." ${ }^{27}$ Descartes's craving for angelic all-at-once-ness emerged forcefully in his mathematics, where he attempted the mental equivalent of Humboldt's pirouette, compressing the steps of mathematical proof into a single bright flare of insight: "I see the whole thing at once, by intuition." 28

\footnotetext{
25 Charlotte Bigg, "The Panorama; or, La Nature à Coup d'Oeil," in Observing Nature-Representing Experience: The Osmotic Dynamics of Romanticism, 1800-1850, ed. Erna Fiorentini (Berlin: Reimer, 2007), pp. 73-95.

${ }^{26}$ Alexander von Humboldt, Kosmos: Entwurf einer physischen Weltbeschreibung (1845-1862), ed. Ottmar Ette und Oliver Lubrich (Frankfurt am Main: Eichborn, 2004), p. 234; and Humboldt, Ansichten der Natur, mit wissenschaftlichen Erläuterungen (1807) (Frankfurt am Main, 2007), p. 109. See the perceptive analysis of Victorian meteorologists' attempts to compress mountains of tabular data into images that could be seized at a glance in Anderson, Predicting the Weather (cit. n. 14), pp. 187-219.

${ }^{27}$ René Descartes, Méditations (1644), in Oeuvres de Descartes, ed. Charles Adam and Paul Tannery, 12 vols. (Paris: Léopold Cerf, 1897-1910), Médiation III, Vol. 9, p. 27; and Ian Hacking, "Leibniz and Descartes," in Historical Ontology (cit. n. 13), pp. 200-213, on p. 204.

${ }^{28}$ René Descartes, Regulae ad directionem ingenium [comp. 1628], in Oeuvres de Descartes, ed. Adam and Tannery, Regula VII, Vol. 10, p. 388: "rem totam simul videar intueri." See also Matthew L. Jones, "Descartes's Geometry as Spiritual Exercise," Critical Inquiry, 2001, 28:40-71.
} 

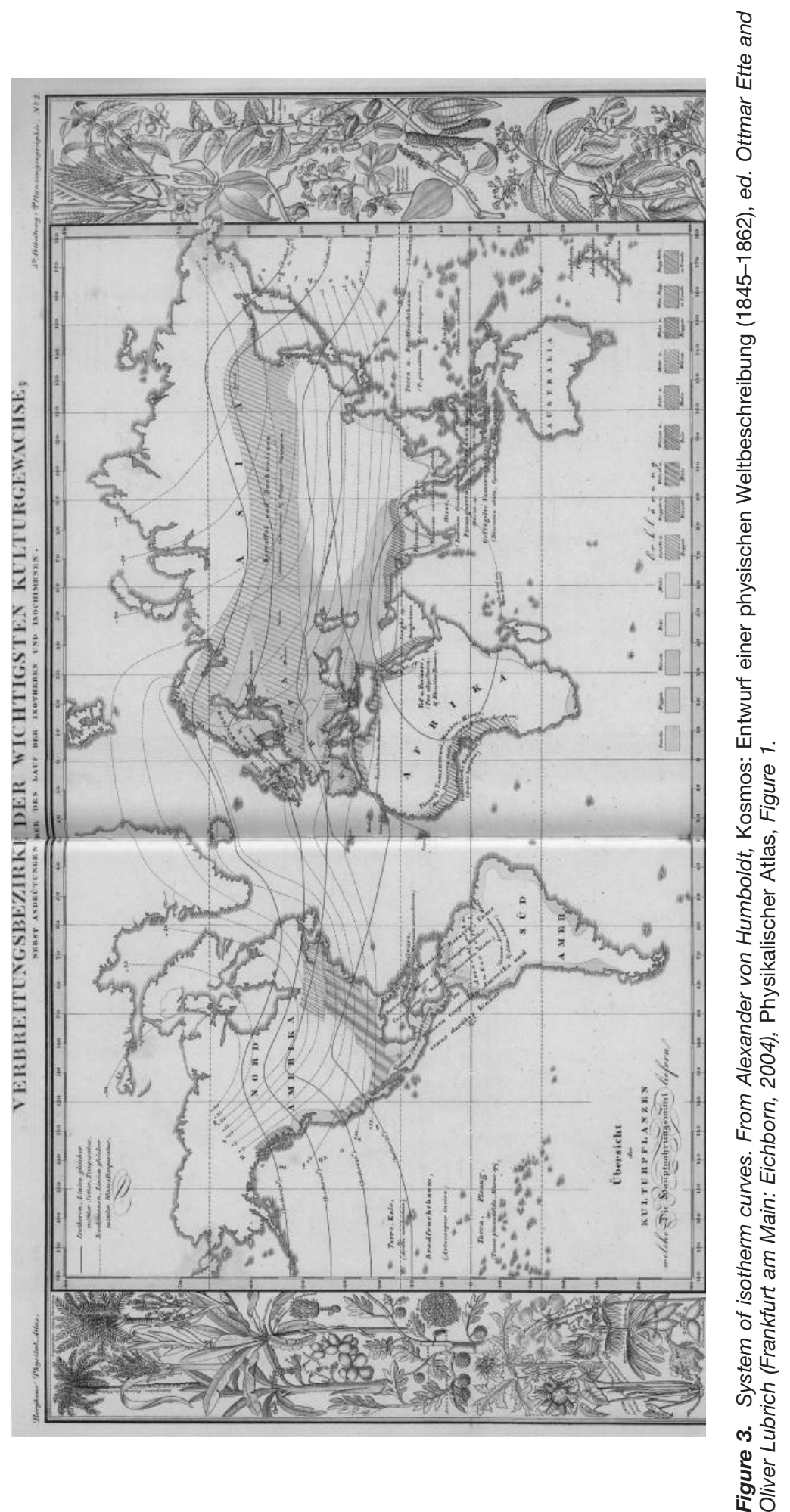

This content downloaded from 141.014.238.123 on April 15, 2019 02:03:27 AM All use subject to University of Chicago Press Terms and Conditions (http://www.journals.uchicago.edu/t-and-c). 
It is telling that Descartes reverts to the language of vision when he describes this kind of cinematic mathematics avant la lettre, in which the argument is so speeded up that it bursts upon the mind as a single cognitive event. For all his talk of closing his eyes and stopping his ears, Descartes cannot resist the self-evidence of perceptual habit when he strikes ontological bedrock. Despite all the well-known illusions, the imprimatur of the real, the true, and the certain is the immediate, implicit all-at-once-ness of perception, especially vision. No amount of explicit reasoning, even mathematical reasoning, can compete with it, at least not for organisms constructed as humans are. Medieval theologians endowed angels with intuitive knowledge because it was their own greatest cognitive good, a foretaste of a paradise without demonstrations and disputations.

Epistemologists and a fortiori metaphysicians may wave aside such claims as "merely psychological." They certainly are psychological, faculties and proclivities peculiar to our own species. Moreover, they concern the largely unconscious processes of perception, albeit processes that are consciously, indeed meticulously, developed, taught, and controlled by the exercise of scientific observation. Perceptual habit may be molded and corrected by reason, but it is not of reason, at least not discursive, conscious, voluntary reason. But this does not render such habits ipso facto irrational. There is nothing individual, nothing arbitrary, nothing mystical about this kind of psychology. Science depends crucially on its own ontologies, so very different from commonsense ontologies, painstakingly assembled from diverse shards of evidence as a mosaic is assembled from thousands of tiny stones of diverse color and shape. It is observation, grounded in trained, collective, cultivated habit, that fuses these bits and pieces into a picture-often a literal picture crafted by techniques of scientific visualization. And it is the picture, seized at a glance, all at once, that guarantees the sturdy existence of a world. This is not quite the vision of angels, who, according to Bonaventure and Aquinas, saw only universal forms, not individual particulars. It is not a metaphysics at all, not a God's eye point of view, but only an ontology for humans, with their eyes wide open. 